Jurnal Media Pertanian Vol. 2 No. 2 Tahun 2017 Hal. 98 - 103

Media Komunikasi Hasil Penelitian dan Review Literatur Bidang Ilmu Agronomi

ISSN print $2503-1279$

ISSN online $2581-1606$

\title{
PENYAKIT BUSUK BUAH TANAMAN KAKAO (Theobroma cacao L. ) SERTA PERSENTASE SERANGANNYA DI DESA BETUNG KECAMATAN KUMPEH ILIR KABUPATEN MUARO JAMBI
}

\author{
Yuza Defitri \\ Program Studi Agroteknologi, Fakultas Pertanian Universitas Batanghari \\ Jl. Slamet Riyadi-Broni-Jambi, 36122 Telp. +62074160103 \\ email : yuzadefitri@yahoo.com
}

\begin{abstract}
Research on foul fruit disease of cacao plants (Theobroma cacao L.) was conducted in the Betung village, Kumpe hilir district, Muaro Jambi regency. This study aims to know about foul fruit diseases and its precentage of illness attacking. Simple Random Sampling was use to determine the samples in this research.The samples weredone in public cocoa farm, that had been stratified base on land passing in level. The symptoms foul fruit desease was observed caused by a phytopthorapalmivora fungus, and those data were entirely collected calculate followed by found out the precentage of attacking fruit. Identification of pathogenic disease was done at Batanghari University laboratory. The result showed that there were the attacking of foul fruit disease caused by a phytophthora palmivora fungus on passing in land was $60.4 \%$ which was means it was hard level of disease as more than half cocoa fruit were foul. While it showed a light of disease attacking on unpassing in land.it's only $7.32 \%$ foul fruit

Keywords : Foul Fruit Disease of Cacao Plants, Phytophthora palmivora
\end{abstract}

\begin{abstract}
Abstrak
Penelitian ini untuk mengkaji penyakit busuk buah serta persentase serangannya pada tanaman Kakao (Theobroma cacao,L.), dilakukan di desa Betung, kecamatan Kumpeh Ilir kabupaten Muaro Jambi. Teknik pengambilan sampel menggunakan metode Simple Random Sampling, sampel tanaman dipilih secara acak di perkebunan kakao rakyat yang sebelumnya sudah dilakukan pengelompokan berdasarkan derajat keterawatan kebun. Pengamatan dilakukan terhadap gejala penyakit busuk buah yang disebabkan oleh jamur Phytopthora palmivora, kemudian dikumpulkan data dengan menghitung seluruh buah baik yang sehat maupun yang sakit sehingga didapat persentase tanaman terserang. Identifikasi terhadap pathogen penyakit dilakukan di Laboratorium Universitas Batanghari Hasil penelitian menunjukkan bahwa persentase serangan penyakit busuk buah yang disebabkan oleh jamur Phytophthora palmivora pada kebun yang tidak dirawat adalah 60.4 $\%$ yang berarti serangan penyakit ini termasuk berat karena lebih setengah buah kakao terserang penyakit. Sedangkan pada kebun yang dilakukan perawatan intensif serangan penyakit busuk buahnya $7.32 \%$ ini berarti serangan penyakit ringan.

Kata Kunci : Penyakit Busuk Buah Kakao, Phytophthora palmivora
\end{abstract}


Jurnal Media Pertanian Vol. 2 No. 2 Tahun 2017 Hal. 98 - 103

Media Komunikasi Hasil Penelitian dan Review Literatur Bidang Ilmu Agronomi

ISSN print $2503-1279$

ISSN online $2581-1606$

\section{PENDAHULUAN}

Kakao (Theobroma cacao L.) termasuk kerajaan: Plantae, Divisi : Magnoliophyta, Kelas Magnoliopsida, Ordo : Malvales, Famili : Malvaceae, Genus Theobroma, Spesies: Theobroma cacao. L. Tanaman kakao terdiri atas dua tipe yang dibedakan dari warna bijinya. Kakao yang bijinya berwarna putih termasuk dalam kelompok Criollo sedangkan biji yang berwarna ungu termasuk dalam kelompok Forastero (Susanto, 2010).

Kakao merupakan salah satu hasil komoditi perkebunan yang memiliki nilai ekonomis yang cukup tinggi diantara tanaman perkebunan yang lainnya dan berperan penting sebagai sumber devisa negara melalui ekspor dan mendorong ekonomi daerah terutama di pedesaan. Untuk itu, sejak tahun 1980 pemerintah memberikan prioritas untuk mengembangkan tanaman kakao sebagai salah satu komoditas unggulan (Susanto, 2010).

Saat ini Indonesia menjadi produsen utama kakao ketiga setelah Ghana dan Pantai Gading. Luas tanaman kakao di Indonesia 1.774.303,97 ha (tahun 2014) dengan produksi 777.500 ton dan sekitar $90 \%$ diusahakan oleh rakyat. Sulawesi merupakan daerah penghasil kakao terbesar di Indonesia. Luas pekebunan kakao Indonesia 60\% terdapat di Sulawesi, yang menyumbang produksi nasional hingga 500 juta ton. Urutan yang kedua adalah Sumatera dengan luas area mendekati 300.000 ha, yang menyumbang produksi hingga 150.000 ton (Direktorat Jendral Perkebunan, 2015).

Menurut Biro Pusat Statistik Provinsi Jambi (2014), luas area tanaman kakao sekitar 2.242 ha dengan produksi 476 ton, sedangkan luas area di kabupaten Muaro Jambi 618 ha dengan produksi 271 ton.

Salah satu penyebab rendahnya produksi tanaman kakao tersebut adalah karena terserang penyakit.. Setiap tahun kerugian yang ditimbulkan bisa mencapai jutaan rupiah setiap hektar tanaman. Penyebab penyakit yang sering dijumpai pada tanaman kakao adalah jamur, sedangkan bakteri atau virus jarang dijumpai dan tidak menimbulkan kerusakan yang berarti (Semangun, 1990 ).

Penyakit Busuk Buah adalah penyakit yang terpenting dalam budidaya kakao di Indonesia dewasa ini, merupakan penyakit yang terpenting di kebanyakan negara penghasil kakao dan banyak menimbulkan kerugian (Agrios, 1999).

Gejala Penyakit Busuk Buah dapat timbul pada berbagai umur buah. Warna buah berubah, umumnya mulai dari ujung buah atau dekat tangkai, yang cepat meluas keseluruh buah. akhirnya buah menjadi hitam. Pada permukaan buah yang sakit dan menjadi hitam tadi timbul lapisan bertepung, terdiri dari jamur-jamur sekunder yang banyak membentuk spora (Semangun, 1990).

Penyakit tanaman di lapangan dapat dikenali berdasarkan tanda dan gejala penyakit. Tanda penyakit merupakan bagian mikroorganisme patogen yang dapat diamati dengan mata biasa yang mencirikan jenis penyebab penyakit tersebut. Misalnya miselia yang berbentuk seperti kapas, merupakan salah satu tanda jamur patogen yang menginfeksi tanaman tersebut. Gejala pada umumnya sangat spesifik tergantung pada spesies yang menginfeksinya, sehingga gejala penyakit tersebut dapat dipergunakan untuk mengidentifikasi jenis patogen yang menginfeksi di lapangan (Agrios, 1999).

Penyakit tanaman dapat mengakibatkan kerugian baik secara kuantitas maupun kualitas hasil panen. Upaya untuk mengurangi kerugian akibat infeksi penyakit tanaman 
Jurnal Media Pertanian Vol. 2 No. 2 Tahun 2017 Hal. 98 - 103

Media Komunikasi Hasil Penelitian dan Review Literatur Bidang Ilmu Agronomi

ISSN print $2503-1279$

ISSN online $2581-1606$

tersebut dapat dilakukan pengendalian dengan sasaran dan cara yang tepat. Pengamatan yang dini dan identifikasi penyakit yang tepat akan menjamin keberhasilan pengendalian (Abadi,2005).

Untuk peningkatan produksi tanaman kakao di desa Betung, kecamatan Kumpeh Ilir perlu diketahui keadaan tanaman kakao yang terserang penyakit dan berapa persentase serangan penyakit tersebut. Hal ini berguna untuk melakukan teknik pengendalian penyakit pada tanaman kakao.

Berdasarkan hal tersebut maka dilakukan penelitian tentang penyakit Busuk Buah serta persentase serangannya.

\section{METODE PENELITIAN}

Penelitian ini dilaksanakan di desa Betung, kecamatan Kumpeh Ilir kabupaten Muaro Jambi dan Laboratorium Universitas Batanghari selama 6 bulan yaitu pada bulan Maret sampai dengan Agustus 2017.

Pengambilan sampel tanaman dilakukan secara acak dengan Simple Random Sampling di perkebunan kakao rakyat. Pengamatan dilakukan terhadap tanaman kakao dengan menghitung seluruh buah baik yang sehat maupun yang sakit sehingga didapat persentase buah kakao yang terserang.

.Tanaman kakao yang diamati adalah yang menunjukkan gejala serangan jamur Phytopthora palmivora. Gejala serangan penyakit busuk buah adalah timbulnya bercakbercak hitam pada bagian kulit luar buah. Bercak-bercak hitam itu akan meluas hingga menutupi semua bagian kulit buah. Buah yang busuk diambil dan dibungkus dengan kertas koran lembab dan masukkan ke dalam kantong plastik, kemudian dibawa ke laboratorium dan disimpan dalam alat pendingin sampai saatnya untuk diidentifikasi.

Pengamatan yang dilakukan di lapangan terhadap tanaman kakao adalah dengan menghitung tanaman dan buah kakao yang ada pada tanaman sampel, baik yang terserang maupun tidak terserang.

Penghitungan persentase buah terserang dilakukan dengan menghitung keseluruhan buah yang ada pada tanaman sampel dan buah yang terserang busuk buah dikelompokkan berdasarkan besarnya gejala yang terdapat pada masing-masing buah. Persentase buah terserang dapat dihitung dengan rumus :

$\mathbf{P b}=\mathbf{a} / \mathbf{b} \times 100 \%$

Keterangan :

$\mathrm{Pb}=$ Persentase buah terserang $(\%)$

$\mathrm{a}=$ Jumlah buah yang terserang

$\mathrm{b}=$ Jumlah buah keseluruhan 
Jurnal Media Pertanian Vol. 2 No. 2 Tahun 2017 Hal. 98 - 103

Media Komunikasi Hasil Penelitian dan Review Literatur Bidang Ilmu Agronomi ISSN print $2503-1279$

ISSN online $2581-1606$

\section{HASIL DAN PEMBAHASAN}

Gejala Penyakit Busuk Buah Kakao (Phytopthora palmivora) ditunjukkan pada gambar di bawah ini
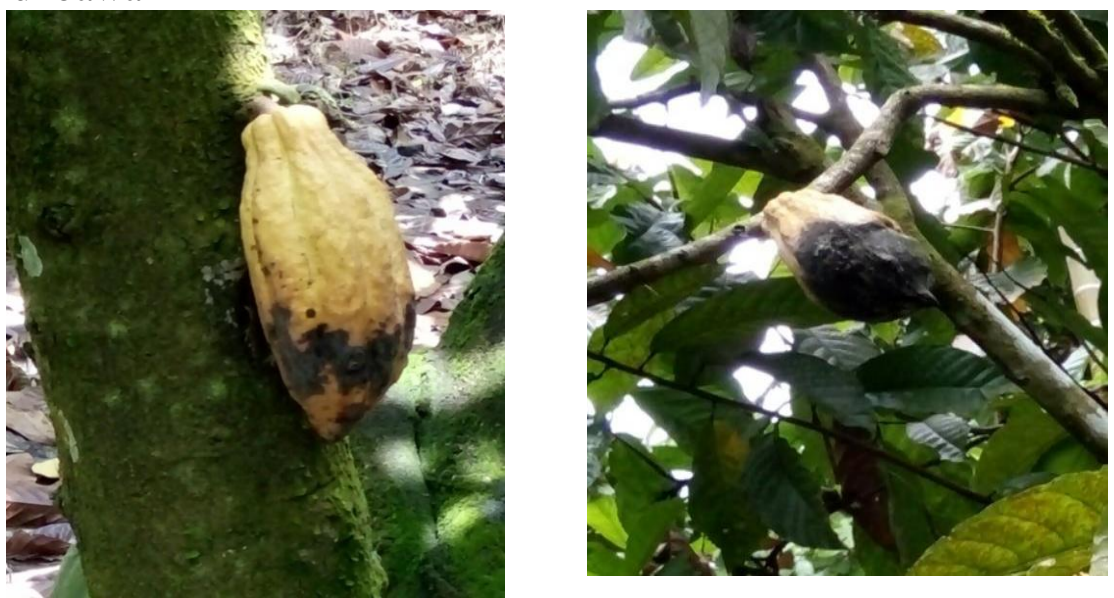

Gambar 1. A. Gejala Busuk Buah Kakao Pada Batang Bawah Tanaman Kakao

B. Gejala Busuk Buah Kakao Pada Ranting Tanaman Kakao

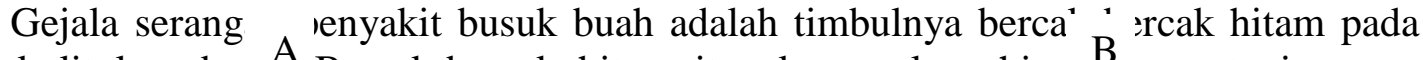
bagian kulit luar bu ${ }^{A}$ Bercak-bercak hitam itu akan meluas hin $\varepsilon_{-}{ }^{B}$ menutupi semua bagian kulit buah jika tidak dilakukan pengendalian. Gejala timbul pada buah dengan berbagai tingkatan umur mulai dari buah masih kecil sampai buah menjelang masak. Warna buah berubah menjadi coklat kehitaman, mulai dari bagian ujung atau dekat dengan tangkai buah. Buah akhirnya menjadi hitam dan sering diselimuti jamur sekunder berwarna putih. Serangan jamur sampai di bagian biji (Abadi, 2005).

Menurut Sinaga (2004), penyakit busuk buah dapat menyerang semua fase pertumbuhan buah, mulai dari buah pentil hingga buah dalam fase kemasakan. Buah yang terserang penyakit busuk buah akan tampak hitam arang dan jika disentuh akan terasa basah membusuk. Penyakit ini dapat menyebar dari satu buah yang terinfeksi ke buah lainnya melalui beberapa media seperti sentuhan langsung antar buah, percikan air, dibawa oleh hewan (semut atau tupai), bahkan oleh tiupan angin. Penyebaran busuk buah akan semakin cepat jika kondisi kebun terlalu lembab karena cendawan Phythoptora palmivora dapat tumbuh subur pada daerah yang lembab (Semangun, 1990).

Persentase buah terserang pada lahan yang tidak dirawat ditampilkan pada Tabel 1

Tabel 1. Persentase Buah Kakao yang terserang penyakit Busuk Buah pada kebun yang tidak dirawat

\begin{tabular}{|c|c|c|c|}
\hline No. Pohon & Buah Sehat & Buah Sakit & Persentase Buah Sakit \\
\hline 1 & 6 & 12 & 66 \\
\hline 2 & 5 & 9 & 64 \\
\hline 3 & 4 & 5 & 55 \\
\hline 4 & 4 & 10 & 71 \\
\hline 5 & 7 & 6 & 46 \\
\hline \multicolumn{2}{|c|}{ Rata-rata Persentase Buah Sakit } \\
\hline
\end{tabular}

Diterbitkan oleh Program Studi Agroteknologi Fakultas Pertanian Universitas Batanghari Jambi

Halaman 101 
Jurnal Media Pertanian Vol. 2 No. 2 Tahun 2017 Hal. 98 - 103

Media Komunikasi Hasil Penelitian dan Review Literatur Bidang Ilmu Agronomi ISSN print $2503-1279$

ISSN online $2581-1606$

Pada kebun tanaman kakao yang tidak dilakukan perawatan yang intensif, yaitu tidak adanya tindakkan pengendalian terhadap hama dan penyakit serangan penyakit busuk buah adalah $60.4 \%$. Hal ini menandakan bahwa serangan penyakit busuk buah yang disebabkan jamur Phytopthora palmivora adalah tergolong berat (lebih dari 50\%). Tanaman kakao dibiarkan saja sehingga kondisi kebun banyak ditumbuhi gulma serta jarak tanam yang tidak teratur yang menyebabkan kelembaban tinggi dan cocok untuk perkembangan jamur pathogen penyebab penyakit.

bawah ini

Persentase buah terserang pada lahan yang dirawat dirangkum pada Tabel 2 di

Tabel 2. Persentase buah Kakao yang terserang penyakit Busuk Buah pada kebun yang dirawat

\begin{tabular}{|c|c|c|c|}
\hline No. Pohon & Buah Sehat & Buah Sakit & Persentase Buah Sakit \\
\hline 1 & 16 & 1 & 5.8 \\
\hline 2 & 17 & 0 & 0 \\
\hline 3 & 11 & 1 & 8.3 \\
\hline 4 & 14 & 2 & 12.5 \\
\hline 5 & 10 & 1 & 10 \\
\hline \multicolumn{3}{|c|}{ Rata-rata Persentase Buah Sakit } \\
\hline
\end{tabular}

Pada kebun tanaman kakao yang dilakukan perawatan intensif seperti mengatur jarak tanam kakao, melakukan pengendalian terhadap hama dan penyakit, menjaga kebersihan kebun dengan melakukan penyiangan maka serangan penyakit busuk buah hanya sekitar $7.32 \%$. Hal ini menandakan serangan penyakit sangat ringan karena tanaman tersebut dirawat dan dikelola dengan baik.

Pengamatan secara mikroskopis terhada jamur patogen penyebab penyakit dapat dilihat pada Gambar 2.

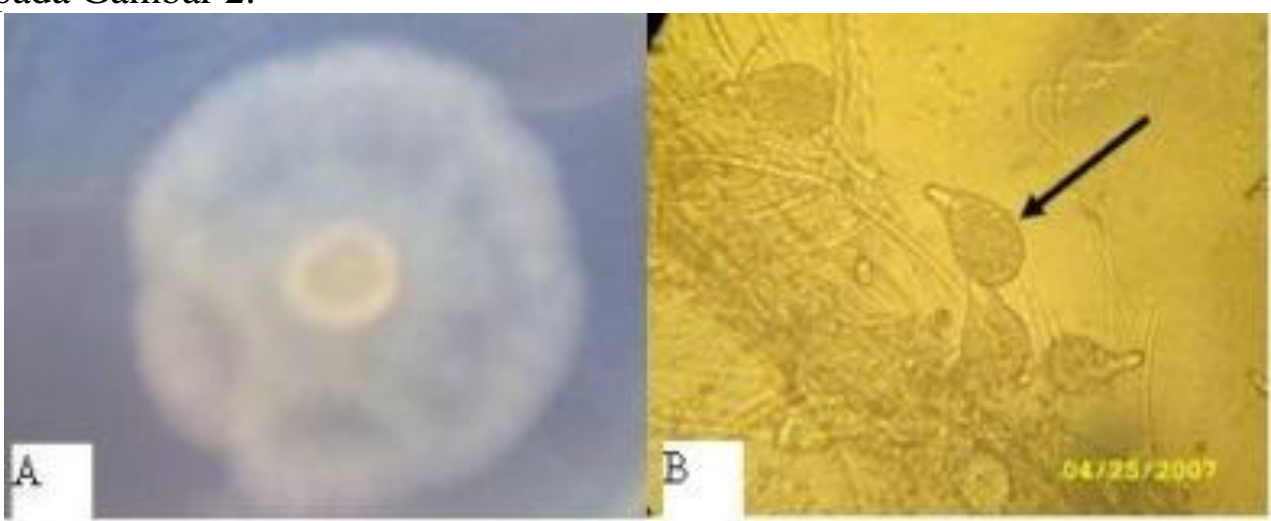

Gambar.2 Phytophthora Palmivora, A. Koloni Jamur dan B. Sporangium (Panah)\

Jamur membentuk struktur sporangium yang berbentuk seperti buah peer. Sporangium dapat berkecambah secara langsung atau membentuk spora kembar yang dapat berenang. Jamur dapat membentuk struktur tahan klamidospora dan spora seksual oospora (Semangun, 1990) 
Jurnal Media Pertanian Vol. 2 No. 2 Tahun 2017 Hal. 98 - 103

Media Komunikasi Hasil Penelitian dan Review Literatur Bidang Ilmu Agronomi

ISSN print $2503-1279$

ISSN online $2581-1606$

\section{KESIMPULAN}

Dari hasil penelitian yang telah dilakukan ditarik kesimpulan bahwa persentase serangan penyakit busuk buah yang disebabkan oleh jamur Phytophthora palmivora pada kebun yang tidak dirawat termasuk berat $(60.4 \%)$, sedangkan pada kebun yang dilakukan perawatan intensif serangan penyakit busuk buah tergolong ringan $(7.32 \%)$.

\section{DAFTAR PUSTAKA}

Abadi, A. 2005. Ilmu Penyakit Tumbuhan. Ilmu Penyakit Tumbuhan. Bayu Media Jakarta Agrios, G. 1999. Ilmu Penyakit Tumbuhan. Gajah Mada University Press Jogyakarta. Biro Pusat Statistik Jambi, 2014. Jambi Dalam Angka, Jambi.

Diretorat Jendral Perkebunan, 2015. Statistik Perkebunan Indonesia Komoditas Kakao 2014 - 1016. Jakarta

Semangun, H. 1990. Penyakit-Penyakit Tanaman Perkebunan di Indonesia. Gajah Mada University Press Jogyakarta.

Sinaga, M. 2004. Dasar-dasar Ilmu Penyakit Tumbuhan. Penebaran Swadaya Jakarta.

Sudiyanto, 2009. Pedoman Bercocok Tanam Cokelat. Direktorat Jenderal Perkebunan, Jakarta.

Susanto, F.X., 2010 . Tanaman Kakao Budidaya Pengolahan Hasil. Kanisius, Jokjakarta. Syamsulbahri, 2008. Bercocok Tanam Tanaman Perkebunan Tahunan, Gajah Mada University Press, Yokyakarta. 